Article

\title{
Impact of Multilateral Trade Liberalization on Resource Revenue
}

\author{
Sena Kimm Gnangnon ${ }^{1}$ and Jean-François Brun ${ }^{2, *}$ \\ 1 World Trade Organization, 154, Rue de Lausanne, CH-1211 Geneva 21, Switzerland; kgnangnon@yahoo.fr \\ 2 Centre d'Etudes et de Recherches sur le Developpement International (CERDI), Université Clermont \\ Auvergne, CNRS, CERDI, F-63000 Clermont-Ferrand, France \\ * Correspondence: j-francois.brun@uca.fr
}

Received: 18 August 2018; Accepted: 8 November 2018; Published: 16 November 2018

\begin{abstract}
This paper investigates the impact of multilateral trade liberalization on resource revenue, using an unbalanced panel dataset comprising 57 countries, including both developed and developing countries, over the period 1995-2015. By means of the two-step system Generalized Methods of Moments (GMM) estimator, the empirical analysis suggests that multilateral trade liberalization exerts a negative effect on resource revenue, probably at the benefit of non-resource revenue. However, this effect over the full sample hides a positive effect of multilateral trade liberalization on resource revenue in poorest countries, and a negative effect of multilateral trade liberalization on resource revenue in non-poorest countries of the sample. Additionally, the negative effect of multilateral trade liberalization on resource revenue over the full sample appears to be dependent on the degree of domestic trade liberalization. In fact, multilateral trade liberalization genuinely induces a reducing effect on resource revenue only if countries liberalize their domestic trade regime beyond a minimum level.
\end{abstract}

Keywords: resource revenue; multilateral trade liberalization; public revenue diversification

JEL Classification: H2; Q28; Q33; F14

\section{Introduction}

There is an abundant literature on the determinants of public revenue, particularly in developing countries (e.g., Khattry and Rao 2002; Ebrill et al. 1999; Agbeyegbe et al. 2006; Brun et al. 2007; Baunsgaard and Keen 2010; Brun et al. 2011; Clist and Morrissey 2011; Thomas and Treviño 2013; Crivelli and Gupta 2014; Brun et al. 2015; Morrissey 2015; Clist 2016; Morrissey et al. 2016; Yohou et al. 2016; Von Haldenwang and Ivanyna 2017). While the bulk of these studies have used either total public revenue or total tax revenue (or the components of the latter) as the measure of public revenue, little attention has been paid to resource revenue. Resource revenue are natural resource revenues, which include a significant component of economic rent, primarily from oil and mining activities. Resource revenue therefore includes tax revenue and non-tax revenue. Only recently had some few studies such as Thomas and Treviño (2013); Crivelli and Gupta (2014); Brun et al. (2015); Omgba (2016) started focusing on the resource revenue component of total public revenue, by particularly looking at the effect of resource revenue on non-resource revenue (but not the determinants of resource revenue). Non-resource revenue refers in the analysis to the part of total public revenue, which is not constituted by resource revenue.

Recent years have witnessed a rise in trade tensions, underpinned by the increasingly frequent adoption of domestic trade restrictive measures (in the form of tariffs and non-tariff measures). A number of factors have been put forth to explain the rise in trade protectionism (see, for example, 
the United Nations document A/72/274). In fact, even though trade liberalization has contributed to lifting millions of people around the world out of poverty, there remains a perception that trade benefits have been unevenly distributed across countries in the world, and across various segments of populations within countries. For example, technological advances and automation, in the context of an ongoing industrial revolution, have been pointed out as being the source of job losses of low and medium-skilled workers as well as of decline in wages.

This backlash against international trade has resulted in a slow progress in multilateral negotiations on trade matters at the WTO, and hence in lower cooperation among WTO Members on trade matters. The rise in trade protectionism measures would likely undermine the effort so far made by Trade Ministers (of countries Members of the World Trade Organization (WTO)) to further liberalize trade at the multilateral level. Recent effort to further liberalize trade at multilateral level involved the adoption by Trade Ministers of several important trade-related Decisions along with the Trade Facilitation Agreement (TFA) at the 2013 Bali Ministerial Conference (held in Bali, Indonesia) and the 2015 Nairobi Ministerial Conferences (held in Nairobi, Kenya). If genuinely implemented, these Decisions and the TFA would lead to greater multilateral trade liberalization, which would provide countries around the world, and especially WTO Members with greater trade opportunities in the international trade markets.

A number of recent studies have investigated the macroeconomic impact of multilateral trade liberalization, including for example on export performance, export revenue instability, economic growth, foreign direct investment inflows, economic development, trade policy, and total public revenue (e.g., Ratnaike 2012; Egger et al. 2004; Gnangnon 2017a, 2017b, 2017c, 2017d, 2017e, 2018a, 2018b). Among these studies, the only one (Gnangnon (2017d)) has explored the link between multilateral trade liberalization and total public revenue. This study has obtained evidence of positive impact of multilateral trade liberalization on total public revenue, with this impact increasing as countries experience higher real per capita income.

The thrust of this paper is to contribute to the macro-public finance literature on the determinants of public revenue by investigating the effect of multilateral trade liberalization on resource revenue. In so doing, it complements the study by Gnangnon (2017d), which has focused only on total public revenue, and has not examined how multilateral trade liberalization influences the components of the total public revenue, for example resource revenue and non-resource revenue components. Additionally, none of the studies have examined the macroeconomic determinants of resource revenue so far, and, in that respect, to the best of our knowledge, the current article appears to be the first one to address this topic.

The empirical analysis covers 57 countries over the period 1995-2015 (using non-overlapping periods of 3-year averages) and uses the two-step system Generalized Methods of Moments (GMM) approach. Results indicate that, while multilateral trade liberalization exerts a negative and significant impact on resource revenue over the full sample, this effect is in fact positive for Least-developed countries (LDCs) and negative for NonLDCs (countries in the sample that are not classified as LDCs). LDCs constitute a category of countries designated by the United Nations as the poorest and most vulnerable in the world. For the list of these countries as well as further details on this group of countries (see online at: http://unohrlls.org/about-ldcs/). Additionally, this negative effect of multilateral trade liberalization on resource revenue depends on the degree of domestic trade liberalization, as the effect is genuinely negative only if countries liberalize their domestic trade regime beyond a minimum level.

The remainder of the paper is structured as follows. Section 2 discusses the theoretical impact of multilateral trade liberalization on resource revenue. Section 3 discusses the appropriate indicators of domestic trade policy and multilateral trade policy to conduct the empirical analysis. Section 4 lays out the model specification that would allow performing the analysis, and discusses the empirical strategy. Section 5 interprets the empirical results. Section 6 deepens the analysis by examining 
whether the effect of multilateral trade liberalization on resource revenue depends on the countries' level of domestic trade policy liberalization. Section 7 provides the conclusions.

\section{Discussion on the Theoretical Impact of Multilateral Trade Liberalization on Resource Revenue}

It is not easy to define and measure 'multilateral trade liberalization'. We follow a number of recent studies (e.g., Gnangnon 2017a, 2017b, 2017c, 2017d, 2017e, 2018a, 2018b) and consider in this study the concept of 'multilateral trade policy liberalization' as all trade-related decisions-including those adopted under the auspices of the WTO — that ultimately contribute to reducing tariffs and non-tariff barriers to international trade for all countries, or at least by the overwhelming majority of them. For example, decisions or agreements (such as the 2013 Trade Facilitation Agreement) adopted by WTO trade ministers at WTO ministerial conferences apply to all WTO members and contribute directly to the liberalization of trade at the multilateral level. Similarly, the reduction of tariffs and/or non-tariff barriers among members of a trading group involving many WTO members would certainly lead to multilateral trade liberalisation if extended to countries that are not members of the group. This is the case, for example, with plurilateral trade agreements, such as the WTO's Information and Technology Agreement (ITA) ${ }^{1}$.

Multilateral trade liberalization could exert two opposite effects on resource revenue. On the one hand, multilateral trade liberalization could help natural resource dependent countries to diversify the sources of public revenue, including away from resource revenue towards non-resource revenue. In this way, it could contribute to reducing the dependence of total public revenue on resource revenue at the benefit of non-resource revenue. The importance of diversifying public revenue away from resource revenue towards non-resource revenue is particularly justified by the fact that, from a policy perspective, non-resource revenue is the most sustainable source of public revenue in the medium- to long-term for any government. How could multilateral trade liberalization then contribute to reducing resource revenue? This could take place through a positive effect of multilateral trade liberalization on (manufacturing) value-added products, including on the diversification of export products ${ }^{2}$, which, in turn, would result in lower resource revenue at the benefit of higher non-resource revenue (for example, Gnangnon and Brun (2017) have shown evidence that export product diversification is conducive to higher non-resource tax revenue). Let us explain the mechanism through which multilateral trade liberalization could negatively affect resource revenue at the benefit of non-resource revenue. In fact, multilateral trade liberalization could provide incentives to firms, including those that have a license to exploit natural resources, to process raw materials and export the final products to the international trade markets, with a view to seizing the opportunities offered by multilateral trade liberalization. Specifically, by reducing tariffs and eventually non-tariff barriers, multilateral trade liberalization would reduce the costs of inputs (and eventually expand the range of inputs) that producers use in the production process of high-value added final goods. This would therefore encourage the processing of natural resource products by both domestic firms and multinational enterprises-MNEs-, including through foreign direct investment (FDI) inflows. Likewise, multilateral trade liberalization could help reduce the number of final exportable goods that are subject to tariff peaks and tariff escalations faced by developing countries' manufactured export products when acceding to the markets of developed

1 The objective of the ITA is to eliminate imports duties on information technology products covered by the agreement. The latter was the first and most significant tariff liberalisation arrangement negotiated in the WTO since its establishment in 1995. At the Nairobi Ministerial Conference in December 2015, over 50 members concluded the expansion of the agreement (see detailed information on the WTO's website https: / / www.wto.org/english/tratop_e/inftec_e/inftec_e.htm, accessed 23 May 2017). Under the present plan, around 65\% of tariffs lines would be eliminated in 2016 (accounting for around 88\% of imports). By $2019,89 \%$ of the tariff lines will be eliminated (representing $95 \%$ of imports). This will reach $100 \%$ over seven years (see Azevêdo 2015).

2 Multilateral trade liberalization could particularly encourage policymakers, including those in resource dependent countries to devise public policies in favour of export product diversification (away from natural resource exports toward higher value-added export products). 
countries. This would particularly enhance the price and quality competitiveness of these countries' producers that are involved in international trade activities. In so doing, multilateral trade liberalization would provide many developing countries, notably poorest countries with further opportunities to improve the quality of their products and diversify their products basket toward higher value-added products. In turn, higher value addition on products would generate higher non-resource revenue (probably at the detriment of resource revenue) through several channels, including the rise in firms' profits and jobs creation. A higher number of jobs in the domestic economy would likely result in a higher (non-resource) personal income tax revenue. Similarly, the positive effect of multilateral trade liberalization on firms' profits would translate into higher non-resource corporate income tax revenue. In addition, the creation of jobs along with the rise in corporate income (firms' profits) would likely lead to higher domestic consumption and/or higher imports, the latter being associated with higher indirect tax revenue (including through higher value added tax (VAT) revenue) and possibly international trade tax revenue. Many of the studies on the determinants of tax revenue performance highlighted in the introduction (e.g., Khattry and Rao 2002; Agbeyegbe et al. 2006; Brun et al. 2007; Baunsgaard and Keen 2010; Brun et al. 2011; Brun et al. 2015; Morrissey et al. 2016) have underlined the positive effect of the higher-valued added manufacturing production on tax revenue. In light of the foregoing, we postulate a first hypothesis (Hypothesis 1) that multilateral trade liberalization could exert a negative effect on resource revenue.

On the other hand, multilateral trade liberalization could lead to higher FDI inflows (for example, resource-seeking multinational enterprises (MNEs)) to host countries (see Collie 2011; Gnangnon 2017a), including in natural resource-dependent countries. As a result, it could generate-although indirectly-higher resource revenue for countries that host these resource-seeking MNEs. Furthermore, if resource-seeking MNEs intend to extract natural resources and send them back to their home country, the government of the host country could collect both higher non-tax resource revenue and tax resource revenue. If the government of the host country levies an export tax on the exports of natural resources, it could additionally collect higher resource revenue. Rather than encouraging the diversification of export products, multilateral trade liberalization could increase countries' specialization in the products in which they have a comparative advantage, especially if those countries (for example, poor countries) do not have a strong trade capacity (for example, productive capacity) to diversify their export products basket and take full advantage of the opportunities offered by greater access to the international trade market. In this context, multilateral trade liberalization would lead resource-rich countries, notably those in developing countries (including poorest ones) to increase the production and export of natural resource products, and hence their specialization in the natural resource sector. This could then be associated with higher resource revenue for the governments of these countries. Against this background, we postulate a second hypothesis (Hypothesis 2) that multilateral trade liberalization could result in higher resource revenue. Overall, while the direction in which multilateral trade liberalization would theoretically influence resource revenue is a priori unknown, we believe that Hypothesis 1 would likely dominate Hypothesis 2 so that the ultimate impact of multilateral trade liberalization on resource revenue would be negative. Notwithstanding this, the empirical analysis would provide further guidance as to which hypothesis prevails over the other.

\section{Measurement of Domestic and Multilateral Trade Policy}

Constructing a macroeconomic indicator of multilateral trade policy is a challenging task. In light of our definition of multilateral trade liberalization, the construction of this indicator would require the choice of an appropriate indicator of domestic trade policy, which should encompass both tariff and non-tariff measures, and concurrently allow calculating the index of multilateral trade policy. 
Following the studies highlighted above ${ }^{3}$ (Ratnaike 2012; Gnangnon 2017a, 2017b, 2017c, 2017d, 2017e, 2018a, 2018b), we use the 'freedom to trade internationally' indicator (denoted here "DTP") proposed by the Heritage Foundation (see Miller et al. 2017) as the measure of domestic trade policy. This index is a composite measure of the absence of tariff and non-tariff barriers that affect imports and exports of goods and services. It comprises two components, namely a trade-weighted average tariff rate and non-tariff barriers (NTBs). The extent of NTBs has been computed using quantitative and qualitative available information. NTBs include quantity restrictions, price restrictions, regulatory restrictions, investment restrictions, customs restrictions, and direct government interventions. The values of the 'freedom to trade internationally' indicator range from 0 to 100 . A rise in these values reflects lower trade barriers, that is, higher domestic trade liberalization, while a decrease in the values of this index reflects rising trade protectionism. Against this background, the indicator of multilateral trade liberalization (denoted "MTP") has been calculated as follows (see Ratnaike 2012; Gnangnon 2017a, 2017b, 2017c, 2017d, 2017e, 2018a, 2018b): for a given country, it is the average score of the 'freedom to trade internationally' indicator of the rest of the world, i.e., of all the other countries (for which data exist), except for the concerned country for which the indicator is being calculated. This allows obtaining over the panel dataset a time-varying variable of multilateral trade liberalization, which reflects for a given country, the extent of multilateral trade liberalization that it could enjoy.

\section{Model Specification and Estimation Strategy}

\subsection{Model Specification}

To examine empirically the impact of multilateral trade liberalization on resource revenue, we draw on the existing literature on the determinants of public revenue (e.g., Ghura 1998; Khattry and Rao 2002; Ebrill et al. 1999; Agbeyegbe et al. 2006; Brun et al. 2007; Baunsgaard and Keen 2010; Thomas and Treviño 2013; Crivelli and Gupta 2014; Brun et al. 2015; Von Haldenwang and Ivanyna 2017). This literature has identified a number of structural factors that influence public revenue. These structural factors (which are control variables used in the current analysis) include the level of development, proxied by countries' real per capita income; the level of trade policy liberalization, demographic characteristics of countries, measured for example by the population size. We have additionally included the inflation rate, which has appeared virtually in almost all studies cited above, and the oil prices, which acts as a proxy for natural resource prices. We also control for the non-resource revenue variable in the model so as to ensure that the impact of multilateral trade liberalization on resource revenue is a direct one, that is, it does not pass through non-resource revenue. We explain below how each of these factors could influence resource revenue.

Against this background, we postulate the following model:

$$
\begin{gathered}
\log (\text { RESREV })_{i t}=\alpha_{0} \quad+\alpha_{1} \log (\operatorname{RESREV})_{i t-1}+\alpha_{2} M T P_{i t}+\alpha_{3} \operatorname{NONRESREV}_{i t}+\alpha_{4} \log (G D P C)_{i t}+\alpha_{5} D T P_{i t} \\
+\alpha_{6} \log (I N F)_{i t}+\alpha_{7} \log (P O P)_{i t}+\alpha_{8} \operatorname{OILPR}_{i t}+\alpha_{9} I N S T_{i t}+\mu_{i}+\omega_{i t}
\end{gathered}
$$

where $i$ is the subscript associated with a given country; $t$ denotes the time-period. The model is estimated using a panel dataset comprising 57 countries, including both developed and developing countries, over seven sub-periods of non-overlapping 3-year average data covering the annual period 1995-2015. These sub-periods include 1995-1997; 1998-2000; 2001-2003; 2004-2006; 2007-2009; 2010-2012 and 2013-2015. The choice of countries and the time period are dictated by data availability. It is worth noting that some variables have been transformed into Logarithm $(\log )$, while others have not. Indeed, we transform into Log all variables that exhibit a high skewness. $\alpha_{0}$ to $\alpha_{9}$ are parameters to be estimated. $\mu_{i}$ are country-specific effects. The disturbance term $\omega_{i t}$ is assumed to be independently

3 A discussion on the choice of this indicator among other indicators of domestic trade policy is provided in Gnangnon (2017a). 
and identically distributed. Table A1 provides the definition and source of the variables used in model (1), while Table A2 reports the list of countries contained in the full sample. Table A3 presents descriptive statistics on these variables.

"RESREV" represents the share (\%) of resource revenue in GDP. As this variable contains yet positive values, but also many zeros, we have transformed it into a Logarithm to limit its skewness. Specifically, as using the natural Logarithm would not be appropriate here, we use the Logarithm transformation method suggested by Yeyati et al. (2007), which goes as follows: $Y=\operatorname{sign}(X) * \log (1+|X|)(2)$, where " $X$ " denotes the variable that is being transformed and " $Y$ " is the variable outcome of the transformation. This method allows for retaining information related to zero observations (see, for example, also Dabla-Norris and Zanna 2015 and Morrissey et al. 2016 who have used this technique in their respective study).

"NONRESREV" stands for the share (\%) of non-resource revenue in GDP. It is the difference between total public revenue and resource revenue, both expressed in \% GDP. We expect an increase in non-resource revenue to be negatively associated with the resource revenue share.

"DTP" and "MTP" are respectively the index of domestic trade policy and the index of multilateral trade policy discussed in Section 3. The literature has demonstrated that domestic trade policy liberalization can exert either a positive or a negative effect on public revenue. Ebrill et al. (1999) and Agbeyegbe et al. (2006) have reported that the impact of trade openness or trade liberalization on public revenue depends on several factors, including the structure of trade liberalization and the effect of the latter on each component of public revenue. As far as the impact of domestic trade policy on resource revenue is concerned, we argue that trade policy liberalization could attract resource-seeking FDI inflows that intend to exploit natural resources, with a view to exporting them to the home countries (these natural resources may be used as inputs in the production process of final goods in the home countries). In this case, trade policy liberalization would induce higher resource revenue. MNEs could also intend to process natural resources in the host country where they have established their plants, in order to export the final products in the international trade market. This may in turn result in higher resource revenue if the government of the host country does not exempt MNEs from paying taxes on the exploitation of these resources. At the same time, the host-country's government can decide to exempt resource-seeking MNEs that intend to exploit and process the natural resource in the host country from paying taxes on the exploitation of the natural resources if it intends to collect higher non-resource revenue. This non-resource revenue would flow from the processed natural resources that are either sold in the domestic market and/or exported in foreign markets. The literature on the determinants of public revenue has established that a higher value added in the manufacturing products (in \% of total output) generates higher non-resource revenue (e.g., Thomas and Treviño 2013; Brun et al. 2015; Gnangnon and Brun 2017). In this context, trade policy liberalization would not result in higher resource revenue, but will likely generate higher non-resource revenue. Overall, it would be difficult to anticipate the (average) impact of trade policy liberalization on resource revenue, as this impact can be either positive or negative.

Brief discussion on the expect impact of control variables on resource revenue

"GDPC" is the real per capita income, a proxy for countries' overall development level. We expect that countries with higher development levels would be better equipped, including in terms of skills and institutional sophistication (for example, strong capacity of the tax administration to collect public revenue) to negotiate better contracts with resource-seeking MNEs. Thus, advanced economies would be able to collect higher resource revenue from the exploitation of natural resources by MNEs than less advanced economies. Therefore, we expect a rise in the real per capita income to be associated with higher resource revenue.

"INF" stands for the inflation rate. We transform this variable into a Logarithm using formula (2) as it contains both negative and positive values. Such transformation also helps reduce the skewness of this variable. According to Tanzi (1977), in an inflationary environment, lags in tax payments reduce 
by the inflation rate, the real amount of tax paid (this effect is further enhanced if the tax system is not protected from inflation). Many studies (among those highlighted above) have reported a negative impact of inflation on public revenue. As far as resource revenue is concerned, we expect that, in an inflationary environment, resource revenue would be adversely (negatively) affected. However, if the government's contracts with MNEs to exploit natural resources are indexed to inflation, the latter would not affect resource revenue.

"POP" is the size of the total population. The size of the population could influence resource revenue through its possible impact on FDI inflows. MNEs that are interested in exploiting natural resources with a view to adding value to these resources and serving the host-country's domestic market (and eventually export abroad, including to the regional markets) could be motivated to set up their plants in host countries that have a high market size, i.e., an important size of the population ${ }^{4}$. The rise in the size of the population could result in higher FDI inflows and generate higher resource revenue for the host-country's government, if the latter does not fully exempt MNEs from the payment of taxes on the exploitation of natural resources. However, the host-country's government could decide to fully exempt MNEs from paying resource revenue (or the government could opt for making MNEs pay miniscule resource revenue) on the exploitation of the natural resources. Such a decision by the government could be based on the expectation that it would collect higher non-resource revenue from the higher value-added products that MNEs would sell in the domestic market, and possibly export. It is important to recall that exports of non-resource products could also be an important source of non-resource revenue as they could generate higher jobs in the tradable sector as well as higher firms' profits. These jobs and the rise in firms' profits would lead to higher non-resource revenue through the channels described in Section 2. In light of all these, it is difficult to anticipate the impact of the size of the population on resource revenue, as this impact could be either positive or negative. The empirical analysis would provide further guidance.

"OILPR" represents the oil prices (deflated by the US consumer price index). It is a proxy for natural resource prices. We expect a rise in natural resource prices to be associated with higher resource revenue.

"INST" represents the indicator (a synthetic measure) of the institutional and governance quality. The importance of institutional and governance quality for public revenue performance has been emphasized in the empirical literature. For example, Ghura (1998) and Bird et al. (2008) have shown empirical evidence that good institutional and governance quality is associated with higher public revenue performance. Therefore, we expect that countries with strong institutional and governance quality would be able to negotiate better contracts on the exploitation of natural resources, and hence collect higher resource revenue. However, as resource revenue is not a sustainable source of public revenue, such countries may opt for diversifying, over the medium to long term, the sources of their public revenue away from resource revenue toward non-resource revenue. We can expect in this context that the better the institutional and governance quality, the lower is the resource revenue share (probably at a higher non-resource revenue share). This argument is particularly relevant because countries with weak institutional and governance quality usually experience difficulties in collecting non-resource tax revenue, and their alternative source of public revenue would therefore be resource revenue. As it could be observed in Table A1, the synthetic measure of institutional and governance quality is computed by means of the factor analysis (notably the Principal Component Analysis). In particular, we use the first principal components of six indicators of governance (for details, see Table A1) (e.g., Buchanan et al. 2012). The Principal Component Analysis approach generates linear combinations of object measures (called eigenvectors), which show the greatest statistical variance

4 A number of empirical studies (Schneider and Frey 1985; Wheeler and Mody 1992; Chakrabarti 2001) have underlined the relevance of the population size (measure of the host-country's market size) for FDI inflows. 
over all of the objects under consideration (six indicators of institutional and governance quality). Higher values of the "INST" indicator represent better institutional and governance quality.

\subsection{Estimation Strategy}

To start with, we estimate by means of the within fixed effects estimator a static version of model (1), i.e., model (1) without the one-period lag of the dependent variable as a regressor. In particular, we correct the estimates' standard errors using the Driscoll and Driscoll and Kraay (1998) technique, which helps take into account the presence of cross-sectional dependence and heteroscedasticity in the error term. We denote "FE-DK" the within fixed effects estimator. The estimates arising from the use of the FE-DK estimator could be biased due to several endogeneity issues, including the reverse causality problem associated with many regressors, as well as the absence of the one-period lag of the dependent variable as a regressor (omitted variable problem). Therefore, following the above-mentioned existing studies on the macroeconomic determinants of public revenue, we also estimate different variants of the dynamic model (1) by means of the two-step system GMM estimator proposed by Arellano and Bond (1991) and Blundell and Bond (1998). The estimation based on the GMM system approach involves a system of equations, i.e., an equation in differences with an equation in levels where lagged first differences are used as instruments for the levels equation, and lagged levels are used as instruments for the first-difference equation. Compared to the first-difference GMM estimator suggested by Arellano and Bond (1991), the two-step system GMM estimator performs better when cross-sectional variability dominates time variability and when there is a strong persistence in the time series under investigation (Blundell and Bond 1998). In addition, when the panel dataset is unbalanced, the difference GMM estimator has a weakness of magnifying gaps (see Roodman 2009). This estimator has the advantage of addressing the endogeneity problem that could stem from the presence of the one-period lag of the dependent variable as a regressor (this problem is referred to as the Nickell bias, see Nickell 1981), as well as other endogeneity issues that could arise from the estimation of model (1). Specifically, the variables "NONRESREV", "GDPC", and "DTP" could be considered as potentially endogenous, due to the eventual reverse causality from the dependent variable to each of these variables. Therefore, in the regressions, we consider all these three variables as endogenous. Standard errors of the estimates obtained by means of the two-step system GMM estimator are corrected using the Windmeijer (2005) finite-sample correction.

We check the validity of the two-step system GMM estimator by relying on three diagnostic tests: the Sargan test of over-identifying restrictions, which helps check the validity of the internal instruments used in the regressions; the Arellano-Bond (AB) tests of first-and second-order serial correlation, respectively denoted $\mathrm{AR}(1)$ and $\mathrm{AR}(2)$ (the null hypothesis of absence of second-order serial correlation in the disturbances should not be rejected, while the null hypothesis of absence of first-order serial correlation should be rejected). Incidentally, we report the AB test of the third-order serial correlation in the error term, denoted $\mathrm{AR}(3)$, to show the lack of autocorrelation at the third order in the error term. We also report the number of instruments used in the regressions, as the above-mentioned diagnostics tests may lose power if the number of instruments is higher than the number of countries (see Roodman 2009).

In a nutshell, the empirical analysis proceeds in several steps. First, we estimate a static specification of model (1) by means of the FE-DK estimator, and the estimation's results are presented in column [1] of Table 1. We then estimate model (1) as it stands, i.e., the dynamic specification of model (1) by means of the two-step system GMM approach. The results of the estimation of this model are reported in column [2] of Table 1. Second, we estimate another specification of model (1), which allows examining whether the impact of multilateral trade liberalization on resource revenue is the same in the poorest countries and the non-poorest countries in the full sample. We consider the least 
developed countries (LDCs) as the poorest countries. LDCs ${ }^{5}$ constitute a group of countries designated as such by the United Nations, which consider them as the poorest and most vulnerable countries in the world. To perform the analysis, we define a dummy variable "LDC", which takes the value 1 when a country belongs to the category of LDCs, and 0, otherwise. The list of the LDCs used in the analysis is displayed in Table A2. This LDC dummy variable is subsequently interacted with the "MTP" variable, and both the dummy variable and its interaction with the "MTP" variable are introduced in model (1). We expect that, as the poorest countries mostly rely on raw materials (including natural resources) for production and exports, and do not have a strong trade capacity ${ }^{6}$, they might not be able to take full advantage of the opportunities offered by multilateral trade liberalization by diversifying their production away from natural resources. In this context, multilateral trade liberalization (i.e., greater access to the international trade market) might increase their specialization in the production and export of natural resources, which would generate higher resource revenue to their governments. The results of the estimation of this specification of model (1) are displayed in Table 2. Before moving to the interpretation of the empirical results, we compare in Figure 1 the evolution of the variables "RESREV", "NONRESREV" and "MTP", using the non-overlapping 3-year average dataset. It is important to note that although the non-resource revenue is not a key variable of interest in the current analysis, its evolution has been presented in Figure 1 with a view to comparing it with that of resource revenue.

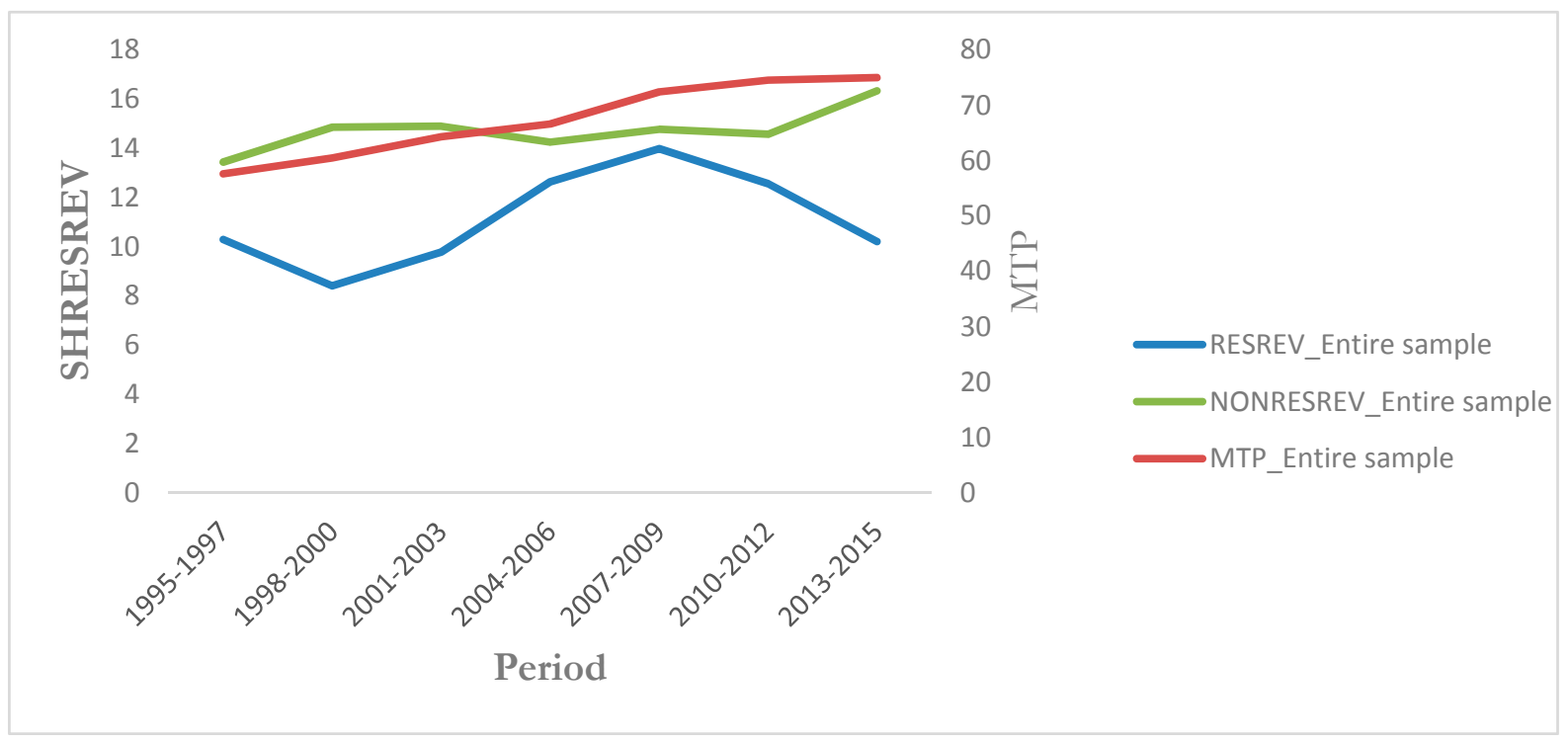

Figure 1. Evolution of "RESREV", “NONRESREV" and "MTP”_Over the Entire sample. Source: Authors.

It could be observed from Figure 1 that multilateral trade liberalization has exhibited an upward trend over the period, thereby suggesting that over time, the world has witnessed greater trade liberalization, albeit steadily. In the meantime, after a decline from $10.3 \%$ in $1995-1997$ to $8.4 \%$ in 1998-2000, resource revenue has steadily increased up to $14 \%$ in 2007-2009. It has then shown a declining trend to reach $10.2 \%$ in 2013-2015. Non-resource revenue has always moved in the opposite direction to resource revenue. It has remained relatively stable around $14.2 \%$ to $14.9 \%$, from $1995-1997$ to $2010-2012$, and has increased from $14.6 \%$ in $2010-2012$ to $16.3 \%$ in $2013-2015$.

5 Further information on LDCs is provided by the United Nations office of the high representative for the least developed countries, landlocked developing countries and small island developing states. See online at: http://unohrlls.org/about$\operatorname{ldcs} /$.

6 The Aid for Trade Initiative of the World Trade Organization (WTO) aims to build trade capacity in developing countries, and particularly LDCs. 
Table 1. Impact of multilateral trade liberalization on total resource revenue. Estimator: FE-DK and Two-Step System GMM.

\begin{tabular}{|c|c|c|c|}
\hline \multirow[b]{2}{*}{ VARIABLES } & \multirow{2}{*}{$\begin{array}{c}\text { FE-DK } \\
\log (\text { RESREV) }\end{array}$} & \multicolumn{2}{|c|}{ Two-Step System GMM } \\
\hline & & Log(RESREV) & Log(RESREV) \\
\hline & (1) & (2) & (3) \\
\hline $\log (\operatorname{RESREV})_{\mathrm{t}-1}$ & & $\begin{array}{l}0.804^{* * *} \\
(0.0462)\end{array}$ & $\begin{array}{l}0.701^{* * *} \\
(0.0480)\end{array}$ \\
\hline MTP & $\begin{array}{c}-0.00674 \\
(0.0111)\end{array}$ & $\begin{array}{c}-0.0372 * * * \\
(0.00561)\end{array}$ & $\begin{array}{c}-0.0338^{* * *} \\
(0.00749)\end{array}$ \\
\hline $\mathrm{LDC}^{*} \mathrm{MTP}$ & & & $\begin{array}{l}0.0378^{* * *} \\
(0.00783)\end{array}$ \\
\hline LDC & & & $\begin{array}{c}-2.886^{* * *} \\
(0.547)\end{array}$ \\
\hline NONRESREV & $\begin{array}{c}-0.0467^{* * * *} \\
(0.00662)\end{array}$ & $\begin{array}{c}-0.0546^{* * *} \\
(0.00665)\end{array}$ & $\begin{array}{c}-0.0728 * * * \\
(0.00837)\end{array}$ \\
\hline $\log (\mathrm{GDPC})$ & $\begin{array}{l}0.287^{* * *} \\
(0.0467)\end{array}$ & $\begin{array}{l}0.119^{* * *} \\
(0.0377)\end{array}$ & $\begin{array}{l}0.160^{* * *} \\
(0.0527)\end{array}$ \\
\hline $\log (\mathrm{INF})$ & $\begin{array}{l}0.0313 * * \\
(0.0137)\end{array}$ & $\begin{array}{c}-0.0330 * * \\
(0.0134)\end{array}$ & $\begin{array}{c}-0.00901 \\
(0.0156)\end{array}$ \\
\hline DTP & $\begin{array}{l}0.00329 * * \\
(0.00125)\end{array}$ & $\begin{array}{l}0.0170 * * * \\
(0.00309)\end{array}$ & $\begin{array}{l}0.0106^{* * *} \\
(0.00391)\end{array}$ \\
\hline $\log (\mathrm{POP})$ & $\begin{array}{l}-0.145 \\
(0.129) \\
\end{array}$ & $\begin{array}{l}-0.0194 \\
(0.0308) \\
\end{array}$ & $\begin{array}{l}-0.0397 \\
(0.0342) \\
\end{array}$ \\
\hline OILPR & $\begin{array}{c}1.192^{* * *} \\
(0.339)\end{array}$ & $\begin{array}{c}0.293 \\
(0.204)\end{array}$ & $\begin{array}{c}0.281 \\
(0.221)\end{array}$ \\
\hline INST & $\begin{array}{c}0.0625 \\
(0.0488)\end{array}$ & $\begin{array}{l}-0.0525 \\
(0.0331)\end{array}$ & $\begin{array}{l}-0.0401 \\
(0.0354)\end{array}$ \\
\hline Constant & $\begin{array}{l}2.516 * \\
(1.441)\end{array}$ & $\begin{array}{c}1.944^{* * *} \\
(0.350)\end{array}$ & $\begin{array}{c}2.658^{* * *} \\
(0.495)\end{array}$ \\
\hline Observations-Countries & $300-57$ & $253-57$ & $253-57$ \\
\hline Within R-squared & 0.3201 & & \\
\hline $\begin{array}{l}\text { Number of } \\
\text { Instruments }\end{array}$ & & 46 & 47 \\
\hline AR1 (P-Value) & & 0.0048 & 0.0074 \\
\hline AR2 (P-Value) & & 0.3908 & 0.6626 \\
\hline AR3 (P-Value) & & 0.5880 & 0.3614 \\
\hline Sargan (P-Value) & & 0.3898 & 0.3358 \\
\hline
\end{tabular}

Note: ${ }^{*} p$-value $<0.1 ;{ }^{* *} p$-value $<0.05 ;{ }^{* * *} p$-value $<0.01$. Robust Standard Errors are in parenthesis. The estimations have been performed using the non-overlapping sub-periods of 3-year average data. The variables "Log(GDPC)", "DTP" and "NONRESREV" have been considered as endogenous. The other variables have been considered as exogenous. In particular, the variable "INST" has been considered as exogenous for two reasons: first, it changes little over time; second the use of factor analysis severely mitigates the endogeneity concern that could stem from the reverse causality from the dependent variable. 
Table 2. Does the impact of multilateral trade liberalization on resource revenue depend on the level of domestic trade policy liberalization? Estimator: Two-Step System GMM.

\begin{tabular}{|c|c|}
\hline VARIABLES & $\log ($ RESREV) \\
\hline & (1) \\
\hline $\log (\operatorname{RESREV})_{\mathrm{t}-1}$ & $\begin{array}{l}0.809 * * * \\
(0.0473)\end{array}$ \\
\hline MTP & $\begin{array}{c}0.0736^{* * *} \\
(0.0174)\end{array}$ \\
\hline DTP*MTP & $\begin{array}{c}-0.00158^{* * *} \\
(0.000262)\end{array}$ \\
\hline NONRESREV & $\begin{array}{l}-0.0632 * * * \\
(0.00639)\end{array}$ \\
\hline $\log (\mathrm{GDPC})$ & $\begin{array}{l}0.114^{* *} \\
(0.0461)\end{array}$ \\
\hline $\log (\mathrm{INF})$ & $\begin{array}{l}-0.0641^{* * *} \\
(0.0228)\end{array}$ \\
\hline DTP & $\begin{array}{l}0.113^{* * *} \\
(0.0168)\end{array}$ \\
\hline $\log (\mathrm{POP})$ & $\begin{array}{c}0.0249 \\
(0.0253)\end{array}$ \\
\hline OILPR & $\begin{array}{c}0.590^{* * *} \\
(0.145)\end{array}$ \\
\hline INST & $\begin{array}{c}-0.00192 \\
(0.0263)\end{array}$ \\
\hline Constant & $\begin{array}{l}-5.340^{* * * *} \\
(1.164)\end{array}$ \\
\hline $\begin{array}{l}\text { Observations-Countries } \\
\text { Within R-squared }\end{array}$ & $253-57$ \\
\hline Number of Instruments & 47 \\
\hline AR1 (P-Value) & 0.0074 \\
\hline AR2 (P-Value) & 0.7695 \\
\hline AR3 (P-Value) & 0.7137 \\
\hline Sargan ( $P$-Value $)$ & 0.2469 \\
\hline
\end{tabular}

Note: ${ }^{*} p$-value $<0.1{ }^{* *} p$-value $<0.05 ; * * *$-value $<0.01$. Robust Standard Errors are in parenthesis. The estimations have been performed using the non-overlapping sub-periods of 3-year average data. The variables "Log(GDPC)", "DTP" and "NONRESREV" have been considered as endogenous. The other variables have been considered as exogenous. In particular, the variable "INST" has been considered as exogenous for two reasons: first, it changes little over time; second the use of factor analysis severely mitigates the endogeneity concern that could stem from the reverse causality from the dependent variable.

\section{Interpretation of Empirical Results}

Before interpreting the estimations' outcomes, let us say a few words on descriptive statistics of key variables of interest used in the analysis, namely DTP, MTP, and RESREV. Statistics provided in Table A3 concerning DTP and MTP show that values of DTP range between 19.7 and 89.3, with an average of 63.7 and a standard deviation amounting to 14.5. Values of MTP range between 57.4 and 75.1, with the average value amounting to 67.25 , and the standard deviation being 6.4 . In the meantime, the minimum value of resource revenue (\% GDP) is 0 , while its maximum value is $63.2 \%$, with an average of 11.2 and a standard deviation of 12.9 .

The estimates reported in column [1] of Table 1 suggest that multilateral trade liberalization exerts no significant impact (at the $10 \%$ level) on resource revenue, although the coefficient of the MTP variable is negative. Results concerning control variables suggest that resource revenue share is positively driven by lower non-resource revenue, higher real per capita income, higher inflation 
rate, domestic trade policy liberalization, and higher oil prices. The population size and the quality of institutions and governance exert no significant impact on resource revenue.

Results reported at the bottom of columns [2] and [3] of Table 1 show that the coefficient associated with the one-period lag of the dependent variable is positive and statistically significant at the $1 \%$ level, thereby confirming that the share of resource revenue in the previous period is positively and significantly related to the current period's share of resource revenue. In addition, the $p$-values associated with the AR (1) test are always lower than 0.01 (the $1 \%$ level of statistical significance) - they should indeed be at least lower than $10 \%$-; the $p$-values relating to the $\operatorname{AR}(2)$ and $\operatorname{AR}(3)$ tests are all higher than 0.10 (the $10 \%$ level of statistical significance); and the Sargan statistic is always associated with a $p$-value higher than $10 \%$. Taken together, all of these outcomes confirm the validity of the two-step system GMM system approach for undertaking the empirical analysis.

Let us now turn to the estimates presented in columns [2] and [3] of Table 1. Results in column [2] suggest that multilateral trade liberalization exerts a negative and significant impact (at the $1 \%$ level) on resource revenue. A 1 standard deviation increase in the index of multilateral trade liberalization (that is a rise in this index by 6.4 -which is relatively important) is associated with a $23.8(=0.0372 \times$ $6.4 \times 100)$ percentage decline in the resource revenue share. The long-term effect of multilateral trade liberalization on the resource revenue share is provided by the short-term effect (which is the estimated coefficient obtained from the regression) divided by 1 minus the coefficient of the one-period lag of the dependent variable. In this specific case, the long-term effect of multilateral trade liberalization on the resource revenue share is given by $0.19[=0.0372 /(1-0.804)]$. This suggests that, over the full sample, in the long term, a 1 standard deviation increase in the index of multilateral trade liberalization is associated with a $121.6(=0.19 \times 6.4 \times 100)$ percentage decline in the resource revenue share, which is a very huge effect in terms of magnitude. In the meantime, results in column [2] of the same Table indicate that while the coefficient associated with MTP is negative and significant at the $1 \%$ level, the interaction term (associated with the interaction variable "LDC*MTP") is positive and statistically significant at the $1 \%$ level. The positive interaction term suggests that multilateral trade liberalization exerts a higher positive effect on the resource revenue share in LDCs than in NonLDCs (countries in the full sample that are not LDCs). The magnitude of the net impact of multilateral trade liberalization on the resource revenue share for LDCs amounts to $0.004(=0.0378-0.0338)$. Hence, for LDCs, a 1 standard deviation increase in the index of multilateral trade liberalization induces a rise by 2.56 $(=0.004 \times 6.4 \times 100)$ percentage of the resource revenue share. The latter result confirms the hypothesis made above concerning the effect of multilateral trade liberalization on resource revenue, whereby it could increase LDCs' specialization in natural resources production and exports, and hence generate higher resource revenue for governments in these countries. The magnitude of the long-term effect of multilateral trade liberalization on the resource revenue share for LDCs is also positive and given by $0.013[=0.004 /(1-0.701)]$. In NonLDCs, multilateral trade liberalization exerts a negative and significant effect on the resource revenue share. The magnitude of this effect is given by the coefficient associated with the MTP variable, which is -0.0338 . This therefore indicates that in NonLDCs, a 1 standard deviation increase in the index of multilateral trade liberalization is associated with a fall in the resource revenue share by $21.6(=0.0338 \times 6.4 \times 100)$ percentage. Hence, NonLDCs tend to diversify their source of public revenue away from resource revenue toward non-resource revenue further to multilateral trade liberalization. The magnitude of the long-term effect of multilateral trade liberalization on resource revenue share in NonLDCs is also negative and given by -0.11 [= $-0.0338 /(1-0.701)]$. With one exception (i.e., concerning the inflation rate), results associated with control variables are similar in columns [2] and [3] of the Table. Specifically, we note that non-resource revenue influences negatively and significantly resource revenue, whereas higher real per capita income and greater domestic trade policy liberalization lead to higher resource revenue share. While the inflation rate exerts a negative and significant effect (at the 5\% level) on the resource revenue share in column [2], it appears to exert no significant effect on the dependent variable in column [3]. The other control variables, namely the population size, the oil price, and the institutional and 
governance quality have no significant impact on the resource revenue share. Overall, the analysis has shown that, while multilateral trade liberalization exerts a negative effect on the resource revenue share over the full sample, the direction of this effect varies across the poorest and the non-poorest countries, as the effect is positive on resource revenue for LDCs, while, for NonLDCs, it is negative.

\section{Further Analysis: Does the Effect of Multilateral Trade Liberalization on Resource Revenue Depend on the Degree of Domestic Trade Policy Liberalization?}

The analysis performed so far has shown that over the full sample, multilateral trade liberalization exerts a negative effect on the resource revenue share, while domestic trade policy liberalization tends to lead to a rise in the resource revenue share. In this section, we question whether the effect of multilateral trade liberalization on the resource revenue share depends on the degree of domestic trade policy liberalization for a given country. This question is all the more relevant that, for the benefits from multilateral trade liberalization to translate into lower resource revenue share, countries should also liberalize their (domestic) trade regimes. For example, even if a country experiences a higher extent of access to the international trade market (i.e., greater multilateral trade liberalization), it would penalize the access of domestic producers and exporters to this market (and domestic consumers as well as) if it raised domestic trade barriers. In other words, in the context of multilateral trade liberalization, higher domestic trade barriers (trade protectionism) would prevent domestic producers from enjoying the decline in products' prices induced by multilateral trade liberalization, and consequently undermine the price and quality competitiveness of those producers involved in international trade activities. Additionally, it would increase import prices (and eventually domestic prices through higher costs borne by domestic producers) for consumers. Against this background and in light of the mechanisms leading to Hypothesis 1 that have been described in Section 2, we hypothesize that greater multilateral trade liberalization would likely not result in lower resource revenue (and hence a diversification of public revenue sources) if, at the same time, the country adopted trade restrictive measures. To test this hypothesis empirically, we estimate a variant of model (1) in which we include the interaction variable capturing the interaction between MTP and DTP variables. This new model specification is estimated by the two-step system GMM approach, the outcomes of which are presented in Table 2.

The results of the diagnostic tests that help check the validity of the two-step system GMM estimator are displayed at the bottom of the Table and are fully satisfactory. In addition, we also obtain that the resource share variable exhibits a state dependence path. Taking together, these outcomes suggest that the two-step system GMM estimator is well appropriate to estimate the new specification of model (1) just described above. Turning now to the estimates presented in this table, two coefficients are of key interest to address the question of whether (and if so, to what extent) the effect of multilateral trade liberalization on resource revenue depends on the degree of domestic trade policy liberalization. These coefficients include the coefficient of the MTP variable and the interaction term associated with the interaction variable "DTP*MTP". While the former is positive and statistically significant at the $1 \%$ level, the latter is negative and statistically significant at the $1 \%$ level. The combination of these two outcomes show that there is a threshold of DTP above which the total effect of multilateral trade liberalization on resource revenue changes sign. This threshold of DTP amounts to 46.6 (=0.0736/0.00158). It is worth recalling that values of DTP range between 19.7 and 89.3 in the full sample. This outcome therefore suggests that, below this threshold, multilateral trade liberalization exerts, on average, a positive effect on the resource revenue share, and, above this threshold, it exerts a positive effect on the resource revenue share. Put differently, multilateral trade liberalization leads to lower resource revenue share (and hence potentially a diversification of public revenue sources toward non-resource revenue) only when the level of domestic trade policy liberalization exceeds the threshold of 46.6. The key conclusion that emerges here is that greater liberalization of domestic trade regimes is key to ensuring a negative effect of multilateral trade liberalization on resource revenue. Even though these results are interesting, they still represent 'average effects' over the full sample, and might therefore not reflect the full picture of the various effects of multilateral trade liberalization 
on resource revenue across countries in the full sample. In fact, these effects could hold different magnitudes, signs and statistical significance across countries of the full sample. A better picture on these impacts is presented in Figure 2, which depicts, at the 95 percent confidence intervals, the evolution of the marginal effect of "MTP" on "RESREV" for different countries' degrees of domestic trade policy liberalization. The statistically significant effects at the 95 percent confidence intervals are those encompassing only the upper and lower bounds of the confidence interval that are either above or below the zero line. The figure shows that the marginal effect of "MTP" on "RESREV" could take positive and negative values, and decreases as countries experience greater domestic trade policy liberalization. However, this marginal effect is not always statistically significant. In particular, it is not statistically significant for values of DTP ranging between 36.4 and 53.1. Thus, countries whose levels of domestic trade policy liberalization range between 36.4 and 53.1 experience no significant effect of multilateral trade liberalization on resource revenue. In contrast, countries with a low level of domestic trade policy liberalization, i.e., lower than 36.4, experience a positive effect of multilateral trade liberalization on resource revenue. In other words, for these countries, multilateral trade liberalization results in higher resource revenue, but the magnitude of this positive effect diminishes as countries further liberalize their trade regimes. Finally, countries that experience a degree of domestic trade policy liberalization higher than 53.1 enjoy a negative effect of multilateral trade liberalization on resource revenue, probably at the benefit of non-resource revenue. In addition, for this set of countries, a higher degree of domestic trade policy liberalization induces a higher reducing effect of multilateral trade liberalization on resource revenue. Overall, we conclude that multilateral trade liberalization is conducive to lower resource revenue (and hence probably a diversification of public revenue source towards non-resource revenue) when countries further liberalize their trade regimes.

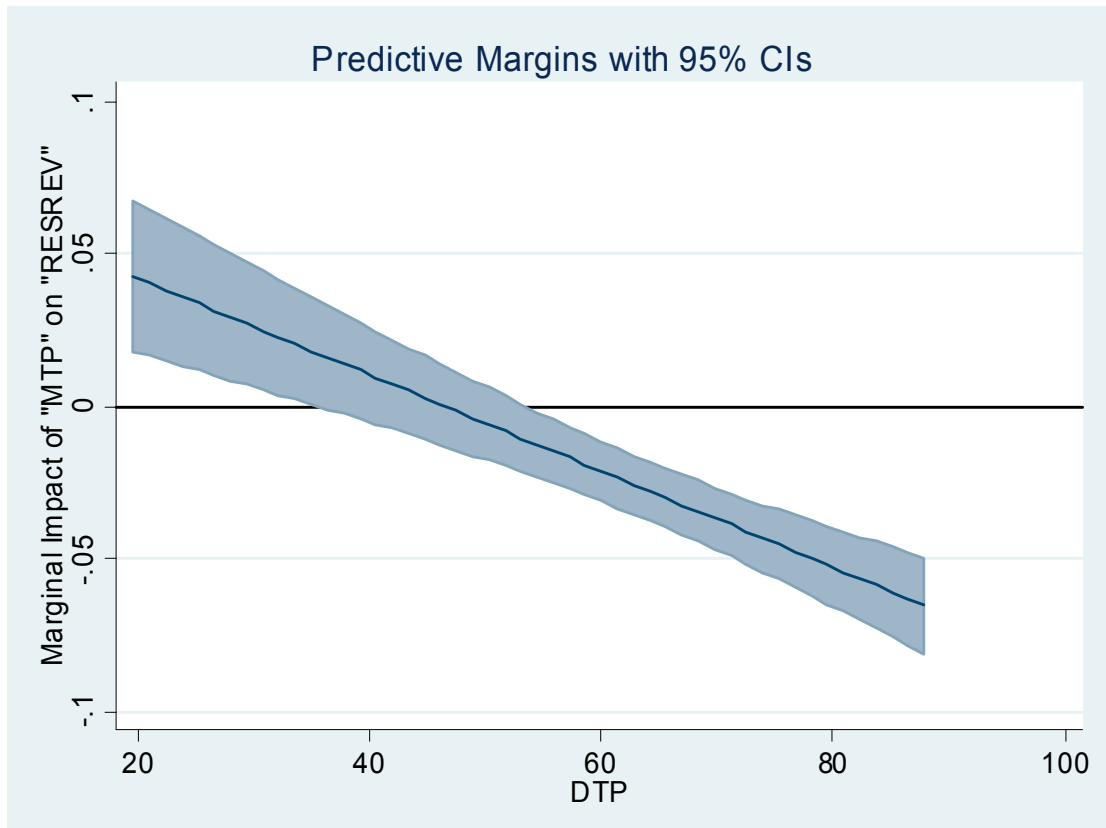

Figure 2. Marginal Impact of "MTP" on "RESREV", for varying countries' levels of domestic trade policy liberalization. Source: Authors.

\section{Conclusions}

This article analyses the impact of multilateral trade liberalization on resource revenue in a sample of 57 countries, including both developed and developing countries, over the period 1995-2015 (using non-overlapping periods of 3-years). The empirical analysis has been carried out by using the two-step system GMM approach. Results suggest that multilateral trade liberalization exerts a negative and significant effect on resource revenue over the full sample. However, this negative effect 
reflects a positive effect of multilateral trade liberalization on resource revenue in the poorest countries (LDCs) and a negative effect of multilateral trade liberalization on resource revenue in the non-poorest countries of the full sample (NonLDCs). Furthermore, the empirical findings indicate that, over the full sample, the effect of multilateral trade liberalization on resource revenue depends on the degree of domestic trade policy liberalization. Specifically, multilateral trade liberalization induces lower resource revenue share (and hence potentially a diversification of public revenue sources toward non-resource revenue) only if it is accompanied with the liberalization of the domestic trade regime (which should reach a minimum level, here 46.6). Otherwise, multilateral trade liberalization induces a higher resource revenue share, which would likely make it difficult for countries to diversify their public revenue sources.

These findings have two policy implications. First, greater cooperation on trade matters among countries in the world, including under the aegis of the WTO, to promote multilateral trade liberalization could help countries reduce the dependence of their total public revenue on resource revenue, and hence facilitates a diversification of public revenue sources toward non-resource revenue. In fact, non-resource revenue remains for governments the most sustainable source of public revenue in the medium- to long-term. However, for this effect to genuinely materialize, countries should liberalize their trade regimes up to a certain level, and should therefore avoid adopting trade protectionism measures in the context of greater multilateral trade liberalization.

Funding: This work has been supported by the Agence Nationale de la Recherche of the French government through the program "Investissements d'avenir", "ANR-10-LABX-14-01". The Authors would therefore like to thank the Agence Nationale de la Recherche of the French government for its support.

Acknowledgments: This paper represents the personal opinions of individual staff members and is not meant to represent the position or opinions of the WTO or its Members, nor the official position of any staff members or even those of the staff of the CERDI- Université Clermont Auvergne. The authors would like to express their sincere gratitude to the anonymous Reviewers for their useful comments on an earlier version this paper. Any errors or omissions are the fault of the authors.

Conflicts of Interest: The authors declare no conflict of interest. 


\section{Appendix A}

Table A1. Variables-Definitions and sources.

\begin{tabular}{|c|c|c|}
\hline Variable & Definition & Source \\
\hline RESREV & $\begin{array}{l}\text { This is the total resource revenue, \% GDP. It is the total natural resource revenues, including } \\
\text { natural resource revenues reported as "tax revenue" or "non-tax revenue". Natural resources } \\
\text { are defined here as natural resources that include a significant component of economic rent, } \\
\text { primarily from oil and mining activities. }\end{array}$ & $\begin{array}{l}\text { ICTD Public revenue Dataset. See online: } \\
\text { http://www.ictd.ac/datasets/the-ictd-government-revenue-dataset }\end{array}$ \\
\hline NONRESREV & $\begin{array}{l}\text { This is the measure of non-resource revenue, in \% GDP. It is the difference between total } \\
\text { public revenue and resource revenue, both expressed, in \% GDP. }\end{array}$ & $\begin{array}{l}\text { Authors' calculation. Data on both total public revenue and resource } \\
\text { revenue are extracted from the ICTD: ICTD Public revenue Dataset. See } \\
\text { online: } \\
\text { http:/ / www.ictd.ac/ datasets/the-ictd-government-revenue-dataset }\end{array}$ \\
\hline DTP & $\begin{array}{l}\text { This is the domestic trade policy. It is measured by the index of "freedom to trade } \\
\text { internationally", which is an important component of the Economic Freedom Index. It is a } \\
\text { composite measure of the absence of tariff and non-tariff barriers that affect imports and } \\
\text { exports of goods and services. Its computation is based on two components: trade-weighted } \\
\text { average tariff rage and non-tariff barriers (NTBs), the extent of latter having been determined } \\
\text { on the basis of quantitative and qualitative available information. NTBs include quantity } \\
\text { restrictions, price restrictions, regulatory restrictions, investment restrictions, customs } \\
\text { restrictions, and direct government interventions. This score is graded on a scale of } 0 \text { to 100, } \\
\text { with a rise indicating lower trade barriers, i.e., higher trade liberalization, while a decrease in } \\
\text { this index reflects rising trade protectionism. }\end{array}$ & Heritage Foundation (see Miller et al. 2017) \\
\hline MTP & $\begin{array}{l}\text { Average trade policy of the rest of the world. For a given country, this variable has been } \\
\text { calculated as the average DTP score of the rest of the world (i.e., for all other countries, } \\
\text { except for the one for which the variable is being calculated). }\end{array}$ & Author's calculation based on Heritage Foundation data. \\
\hline GDPC & GDP per capita (constant 2010 US\$) & WDI \\
\hline INF & Inflation rate $(\%)$ & WDI \\
\hline POP & Total population & WDI \\
\hline OILPR & $\begin{array}{l}\text { These are the oil prices, in US Dollars, deflated by the Index of United States' Consumer } \\
\text { Price Index for All Urban Consumers. }\end{array}$ & $\begin{array}{l}\text { Data on both the oil prices and the US consumer price index are extracted } \\
\text { from the Federal Reserve Economic Data (see online at: } \\
\text { https: / / fred.stlouisfed.org) }\end{array}$ \\
\hline INST & $\begin{array}{l}\text { This is the variable capturing institutional quality in a given country. It has been computed } \\
\text { by extracting the first principal component (based on factor analysis) of the following six } \\
\text { indicators of governance. These indicators include an index of political stability and absence } \\
\text { of violence/terrorism; an index of regulatory quality; an index of rule of law; an index of } \\
\text { government effectiveness; an index of Voice and Accountability; and an index of } \\
\text { corruption.It is worth noting that higher values of the index "INST" are associated with } \\
\text { better governance and institutional quality, while lower values reflect worse governance and } \\
\text { institutional quality. }\end{array}$ & $\begin{array}{l}\text { Data on the components of "INST" variable has been extracted from } \\
\text { World Bank Governance Indicators developed by Kaufmann et al. (2010) } \\
\text { and recently updated. }\end{array}$ \\
\hline
\end{tabular}


Table A2. List of countries contained in the full sample and the sub-sample of LDCs.

\begin{tabular}{cccc}
\hline & Entire Sample & & LDCs \\
\hline Algeria & Indonesia & Qatar & Angola \\
\hline Angola & Iran, Islamic Rep. & Russian Federation & Burkina Faso \\
\hline Azerbaijan & Israel & Sao Tome and Principe & Chad \\
\hline Bahrain & Jamaica & Saudi Arabia & Equatorial Guinea \\
\hline Bolivia & Kazakhstan & Senegal & Guinea \\
\hline Botswana & Kuwait & Serbia & Lao PDR \\
\hline Brunei Darussalam & Lao PDR & Sierra Leone & Liberia \\
\hline Burkina Faso & Liberia & Sudan & Mauritania \\
\hline Cameroon & Libya & Suriname & Niger \\
\hline Chad & Malaysia & Timor-Leste & Sao Tome and \\
\hline Chile & Mauritania & Togo & Senegal \\
\hline Colombia & Mexico & Trinidad and Tobago & Sierra Leone \\
\hline Congo, Rep. & Moldova & Tunisia & Sudan \\
\hline Cote d'Ivoire & Mongolia & Uganda & Timor-Leste \\
\hline Egypt, Arab Rep. & Namibia & Venezuela, RB & Togo \\
\hline Equatorial Guinea & Niger & Vietnam & Uganda \\
\hline Gabon & Nigeria & Yemen, Rep. & Yemen, Rep. \\
\hline Ghana & Norway & Zambia & \\
\hline Guinea & Papua New Guinea & & \\
\hline
\end{tabular}

Table A3. Standard descriptive statistics on variables used in model (1).

\begin{tabular}{cccccc}
\hline Variable & Observations & Mean & Standard Deviation & Minimum & Maximum \\
\hline RESREV & 328 & 11.225 & 12.851 & 0.000 & 63.204 \\
MTP & 399 & 67.252 & 6.417 & 57.363 & 75.102 \\
DTP & 368 & 63.723 & 14.494 & 19.733 & 89.300 \\
NONRESREV & 326 & 14.781 & 7.571 & 1.742 & 36.833 \\
GDPC & 394 & 8434.716 & $15,361.140$ & 157.565 & $90,204.810$ \\
INF & 390 & 81.415 & 1241.282 & -6.934 & $24,411.030$ \\
INST & 397 & -1.104 & 1.661 & -4.794 & 4.412 \\
OILPR & 399 & 0.262 & 0.126 & 0.117 & 0.449 \\
POP & 399 & $2.44 \times 10^{7}$ & $4.20 \times 10^{7}$ & $127,916.7$ & $2.54 \times 10^{8}$ \\
\hline
\end{tabular}

\section{References}

Agbeyegbe, Terence, Janet Gale Stotsky, and Asegedech WoldeMariam. 2006. Trade Liberalisation, Exchange Rate Changes and Tax Revenue in Sub-Saharan Africa. Journal of Asian Economics 17: 261-84. [CrossRef]

Arellano, M., and S. Bond. 1991. Some Tests of Specification for Panel Data: Monte Carlo Evidence and an Application to Employment Equations. Review of Economic Studies 58: 277-97. [CrossRef]

Azevêdo, R. 2015. Information Technology Agreement press conference: Remarks by Director-General Roberto Azevêdo. December 16. Available online: https://www.wto.org/english/news_e/spra_e/spra104_e.htm (accessed on 23 May 2017).

Baunsgaard, Thomas, and Michael Keen. 2010. Tax Revenue and (or?) Trade Liberalization. Journal of Public Economics 94: 563-77. [CrossRef]

Bird, Richard M., Jorge Martinez-Vazquez, and Benno Torgler. 2008. Tax Effort in Developing Countries and High Income Countries: The Impact of Corruption, Voice and Accountability. Economic Analysis and Policy 38: 55-71. [CrossRef] 
Blundell, Richard, and Stephen Bond. 1998. Initial Conditions and Moment Restrictions in Dynamic Panel Data Models. Journal of Econometrics 87: 115-43. [CrossRef]

Brun, Jean-François, Gerard Chambas, and Samuel Guerineau. 2007. Aide et mobilisation fiscale dans les pays en développement. AFD Jumbo, Rapport Thématique. 21. Paris: Agence Française de Développement (AfD) Département de la Recherch.

Brun, J.-F., G. Chambas, and B. Laporte. 2011. IMF Programs and Tax Effort What Role for Institutions in Africa? CERDI Etudes et Documents. 2010.33. Clermont-Ferrand: CERDI, Université d'Auvergne.

Brun, Jean-François, Gerard Chambas, and Mario Mansour. 2015. Tax Effort of Developing Countries: An Alternative Measure. In Financing Sustainable Development Addressing Vulnerabilities. Edited by Matthieu Boussichas and Patrick Guillaumont. Paris: Fondation pour les études et recherches sur le développement international (FERDI) in association with Éditions Economica, chp. 11.

Buchanan, Bonnie G., Quan V. Le, and Meenakshi Rishi. 2012. Foreign direct investment and institutional quality: Some empirical evidence. International Review of Financial Analysis 21: 81-89. [CrossRef]

Chakrabarti, Avik. 2001. The Determinants of Foreign Direct Investments: Sensitivity Analyses of Cross-Country Regressions. Kyklos 54: 89-113. [CrossRef]

Chelliah, Raja J. 1971. Trends in Taxation in Developing Countries. IMF Staff Papers 18: 254-332. [CrossRef]

Choi, Changkyu, and Myung Hoon Yi. 2009. The effect of the internet on economic growth: Evidence from cross-country panel data. Economic Letters 105: 39-41. [CrossRef]

Clist, Paul. 2016. Foreign aid and domestic taxation: Multiple sources, one conclusion. Development Policy Review 34: 365-83. [CrossRef]

Clist, Paul, and Oliver Morrissey. 2011. Aid and Tax Revenue: Signs of a Positive Effect since the 1980s. Journal of International Development 23: 165-80. [CrossRef]

Collie, David R. 2011. Multilateral Trade, Foreign Direct Investment and the Volume of World Trade. Economics Letters 113: 47-49. [CrossRef]

Crivelli, Ernesto, and Sanjeev Gupta. 2014. Resource Blessing, Revenue Curse? Domestic Revenue Effort in Resource-Rich Countries. European Journal of Political Economy 35: 88-101. [CrossRef]

Dabla-Norris, Era Camelia Minoiu, and Luis-Felipe Zanna. 2015. Business Cycle Fluctuations, Large Macroeconomic Shocks, and Development Aid. World Development 69: 44-61. [CrossRef]

Dollar, David. 1992. Outward-Oriented Developing Economies Really Do Grow More Rapidly: Evidence from 95 LDCs, 1976-85. Economic Development and Cultural Change 40: 523-44. [CrossRef]

Driscoll, John C., and Aart C. Kraay. 1998. Consistent Covariance Matrix Estimation with Spatially Dependent Panel Data. Review of Economics and Statistics 80: 549-60. [CrossRef]

Ebrill, Liam, Janet Stotsky, and Reint Gropp. 1999. Revenue Implications of Trade Liberalization. IMF Occasional Paper 99/80 International Monetary Fund. Washington: IMF.

Egger, Peter, Mario Larch, and Michael Pfaffermay. 2004. Multilateral trade and investment liberalization: effects on welfare and GDP per capita convergence. Economics Letters 84: 133-40. [CrossRef]

Ghura, Dhaneshwar. 1998. Tax Revenue in Sub-Sahara Africa: Effects of Economic Policies and Corruption. WP/98/135. Washington: International Monetary Fund.

Globerman, Steven, and Daniel Shapiro. 2002. Global foreign direct investment flows: the role of governance infrastructure. World Development 30: 1899-919. [CrossRef]

Gnangnon, Sèna Kimm. 2017a. Multilateral Trade Liberalization and Foreign Direct Investment Inflows. Economics Affairs 37: 66-84. [CrossRef]

Gnangnon, Sèna Kimm. 2017b. The Impact of Multilateral Trade Liberalization on Economic Development: Some Empirical Evidence. Economic Affairs 37: 397-410. [CrossRef]

Gnangnon, Sèna Kimm. 2017c. Effect of multilateral trade liberalization on foreign direct investment outflows amid structural economic vulnerability in developing countries. Research in International Business and Finance 45: 15-29. [CrossRef]

Gnangnon, Sèna Kimm. 2017d. Multilateral Trade Liberalization and Public revenue. Journal of Economic Integration 32: 586-614. [CrossRef]

Gnangnon, Sèna Kimm. 2017e. Multilateral Trade Liberalization, Export Share in the International Trade Market and Aid for Trade. Journal of International Commerce, Economics and Policy 08: 1750014. [CrossRef]

Gnangnon, Sèna Kimm. 2018a. Impact of multilateral trade liberalization and aid for trade for productive capacity building on export revenue instability. Economic Analysis and Policy 58: 141-52. [CrossRef] 
Gnangnon, Sèna Kimm. 2018b. Multilateral Trade Liberalization and Economic Growth. Journal of Economic Integration 33: 1261-301. [CrossRef]

Gnangnon, Sèna Kimm, and Jean-François Brun. 2017. Impact of export upgrading on tax revenue in developing and high-income countries. Oxford Development Studies 45: 542-61. [CrossRef]

Kaufmann, Daniel, Aart Kraay, and Massimo Mastruzzi. 2010. The Worldwide Governance Indicators Methodology and Analytical Issues, World Bank Policy Research $N^{\circ} 5430$ (WPS5430). Washington: World Bank.

Khattry, Barsha, and Mohan J. Rao. 2002. Fiscal Faux Pas?: An analysis of the revenue implications of trade liberalization. World Development 30: 1431-44. [CrossRef]

Miller, Terry, Anthony B. Kim, James M. Roberts, Bryan Riley, and Tori Whiting. 2017. 2017 Index of Economic Freedom, Institute for Economic Freedom, The Heritage Foundation, Washington, DC. Available online: http:/ / www.heritage.org/index/download (accessed on 23 November 2016).

Morrissey, Oliver. 2015. Aid and Government Fiscal Behavior: Assessing Recent Evidence. World Development 69: 98-105. [CrossRef]

Morrissey, Oliver, Christian Von Haldenwang, Armin Von Schiller, Maksym Ivanyna, and Ingo Bordon. 2016. Tax Revenue Performance and Vulnerability in Developing Countries. Journal of Development Studies 52: 1689-703. [CrossRef]

Nickell, S. 1981. Biases in Dynamic Models with Fixed Effects. Econometrica 49: 1417-26. [CrossRef]

Omgba, Luc Désiré. 2016. On the Mobilization of Domestic Resources in Oil Countries: The Role of Historical Factors. UNU-WIDER Working Paper 2016/154. Helsinki, Finland: UNU-WIDER.

Paunov, Caroline, and Valentina Rollo. 2016. Has the Internet Fostered Inclusive Innovation in the Developing World? World Development 78: 587-609. [CrossRef]

Ratnaike, Yasanji C. 2012. Is there an empirical link between trade liberalisation and export performance? Economics Letters 117: 375-78. [CrossRef]

Roodman, David. 2009. A note on the theme of too many instruments. Oxford Bulletin of Economic and Statistics 71: 135-58. [CrossRef]

Sachs, Jeffrey. D., and Andrew Warner. 1995. Economic Reform and the Process of Global Integration. Brookings Papers on Economic Activity 26: 1-118. [CrossRef]

Schneider, Friedrich, and Bruno S. Frey. 1985. Economic and political determinants of foreign direct investment. World Development 13: 161-75. [CrossRef]

Tanzi, Vito. 1977. Inflation, Lags in Collection, and the Real Value of Tax Revenue. Staff Papers. International Monetary Fund 26: 154-67. [CrossRef]

Thomas, Alun H., and Juan P. Treviño. 2013. Resource Dependence and Fiscal Effort in Sub-Saharan Africa. IMF Working Paper, WP/13/188. Washington, DC, USA: International Monetary Fund.

United Nations Conference on Trade and Development (UNCTAD). 2017. International Trade and Development. Report of the Secretary-General of UNCTAD Prepared for the UNCTAD's Seventy-Second Session, Document A/72/274. Geneva: United Nations Conference on Trade and Development.

Von Haldenwang, Christian, and Maksym Ivanyna. 2017. Does the Political Resource Curse Affect Public Finance? The Vulnerability of Tax Revenue in Resource-Rich Countries. UNU-WIDER Working Paper 2017/7. Helsinki, Filand: UNU-WIDER.

Wheeler, David, and Ashoka Mody. 1992. International investment location decisions: the case of US firms. Journal of International Economics 33: 57-76. [CrossRef]

Windmeijer, Frank. 2005. A finite sample correction for the variance of linear efficient two-step GMM estimators. Journal of Econometrics 126: 25-51. [CrossRef]

Yeyati, EduardoLevy, Ugo Panizza, and Ernesto Stein. 2007. The cyclical nature of North-South FDI flows. Journal of International Money and Finance 26: 104-30. [CrossRef]

Yohou, Hermann D., Michaël Goujon, and Wautabouna Ouattara. 2016. Heterogeneous Aid Effects on Tax Revenues: Accounting for Government Stability in WAEMU Countries. Journal of African Economies 25: 468-98. [CrossRef]

(C) 2018 by the authors. Licensee MDPI, Basel, Switzerland. This article is an open access article distributed under the terms and conditions of the Creative Commons Attribution (CC BY) license (http://creativecommons.org/licenses/by/4.0/). 